\title{
Jurisdictional Review of Legal Protection Against Land Rights Owner in The Event of Multiple Certificates
}

\author{
Iqriyah Petta Minnon ${ }^{1}$, Evita Isretno Israhadi ${ }^{2}$ \\ \{iqriyah@yahoo.co.id ${ }^{1}$,evita_isretno@borobudur.ac.id² \\ Universitas Borobudur, Jakarta, Indonesia ${ }^{1,2}$
}

\begin{abstract}
The endorsement is a letter of confirmation of land freedoms or proof of land privileges guideline which comprises of a duplicate of the land book and an estimating archive bound together in a report cover for the comfort of the right holder concerned. This examination expects to depict the variables that can prompt the development of twin land privileges declarations and investigate the lawful security that land owners have if they have double certificates. The methodology utilized in this exploration is regulating juridical law research, and the kind of examination is library research. The review reasoned that the elements causing double endorsements of land privileges, among others, were specialized blunders during estimation, the presence of a letter of proof or affirmation of freedoms (lie, bogus, or as of now not substantial), land legacy freedoms, and covering in the issuance of land privileges declarations, alluded to as regulatory legalism.
\end{abstract}

Keywords: Dual Certificate; Legal Security; Land Ownership

\section{Introduction}

The land has an essential meaning for the life of the Indonesian people, where the Indonesian State is an agricultural country, so that every activity carried out by the majority of the Indonesian people always requires and involves land.[1] Land is a principal human need as a result of the exercises completed by people on the ground. Each time people are consistently in touch with land, one might say that practically movements of every sort of human existence, either straightforwardly or in a roundabout way, consistently require land.[2]

The need for land is increasing with the increasing population explosion.[3] The supply of land is limited (unchanged), so controlling land and natural resources becomes increasingly important and strategic.[4] The availability of land for human life is essential for various purposes, both as residential land and as productive land such as industrial, agricultural, plantation, and fishery facilities. Directly or indirectly, the land is a necessary factor of production in producing all other goods, so that it can be said that land is the source of all other wealth. The land is a natural resource that gives life to human resources.[5]

Human legal relations with land are concreted through land rights institutions. Legal certainty of land rights is the starting point for handling and managing land problems so that the land itself has a productive value for the life of the land-owning community. Constitutionally, the 1945 Constitution of the Republic of Indonesia in Article 33 section (3) 
expresses that "earth, water, space and regular assets contained in that are constrained by the State and utilized for the best thriving individuals." Observing these early on arrangements, it tends to be seen that the success of individuals is the primary objective in the usage of the elements of the earth, water, and space, and the normal assets contained in that.

Law Number 5 of 1960 concerning Basic Regulations on Agrarian Principles proclaimed on September 24, 1960,[6] known as the UUPA, carried out Article 33 passage (3) of the 1945 Constitution. Prior to the establishment of the UUPA, just grounds that were dependent upon Western law, for instance, Eigendom Rights, Impact Rights, Opstal Rights, land enlistment is done to give legitimate conviction ensures, and the holder is given proof with a deed made by the Transfer Officer.

With the introduction of the UUPA, public agrarian law will be acknowledged, which will give lawful sureness to all individuals and empower the accomplishment of the elements of earth, water and space, and regular abundance as desired. Thinking about the nature and position of this LoGA as a fundamental guideline for the new public farming law, this LoGA just holds back the standards and essential inquiries of rural issues. To ensure privileges and lawful assurance over land, the LoGA has laid out the need to complete land enlistment all through Indonesia.

In general, ownership of land rights can be obtained in several ways that several people in the community have commonly applied, such as hereditary, controlling, and owning based on inheritance rights, or the distribution of property gono-gini. It can also be because they intentionally enter into certain legal relationships, giving them land rights, such as grants, buying, selling, or leasing. Unfortunately, the process of transferring ownership of land rights is not accompanied by solid legal evidence. Still, it is only based on a relationship of trust alone, often denying proof of ownership of land rights. This method is still used by some in our society, especially those who live in rural areas.

Law Number 5 of 1960 concerning Basic Regulations on Agrarian Principles specifies how different instruments should be followed to get responsibility for freedoms. Specifically, by applying land freedoms to the State through the State Land Agency, composed with the significant neighborhood government. Most individuals once in a while know the system for getting land freedoms like this of the local area.

Responsibility for freedoms acquired dependent on an application to the State will without a doubt have more considerable proof than proprietorship dependent on innate legacy or exchanges between local area individuals, which are by and large not circled back to changes in the verification of land privileges. Unofficial law Number 24 of 1997 concerning Land Registration is a refinement of Government Regulation Number 10 of 1961, which specifies that land enrollment has moved forward to accomplish flawlessness in executing land enlistment in Indonesia. The last course of land enlistment is the issuance of a testament of land freedoms as strong proof.

A testament is a letter of confirmation of land privileges or method for proof with respect to the control of land freedoms, which comprises of a duplicate of the land book and an estimating record bound together in an archive cover to help the right holder concerned. The authentication may just be submitted to the party whose name is recorded in the land book worried as the right holder or to one more party approved by him. Sorts of freedoms other than the name of the holder, portrayal of actual information ashore, and records of occasions identified with the ground (e.g., records of move of proprietorship, deal and buy, awards, and so on)

Endorsements can be utilized as insurance to expand business capital and increment the selling cost of land. Authentications additionally have financial worth. Kinds of land 
privileges in the land testament incorporate the sorts of land freedoms. Consider it the Right to Build, Right to Own, Right to Use, Right to Cultivate, and Right to Management. Data on the sorts of land privileges additionally incorporates the legitimacy time of these freedoms, like HGB for a specific period. There is no time limit on the legitimacy time of the Property Rights.

However, in reality, these regulations have not fully protected land rights holders. Not infrequently because of the immense value of the land, it often causes conflicts both vertically and horizontally. The fact is, in the issuance of certificates, there are still multiple issuances of certificates, meaning the distribution of more than one certificate whose lands overlap in whole or in part.

Land certificates recorded the transfer of land rights as an illustration. If the landowner makes a sale and purchase transaction, the name of the previous right holder will be crossed out by the local Land Office official. After the land sale and purchase process is completed, the name of the new right holder will be included. Therefore, through land certificates, it can be known who the holders of land rights are. There are still several cases of land disputes caused by dual land certificates against the same land. There should not be expected to happen because, to issue a land certificate, BPN should have previously carried out some re-check on the land master book, whether it was recorded as having given a certificate or not. This case often involves fellow citizens or residents dealing with corporations in the conflict over land ownership. In the end, those who are related to this legal case will settle it in court. Therefore, the earlier certificate may have a weak legal basis to be defeated in the trial. Or it could even be that BPN elements are wrong for issuing certificates on land that are already certified, depending on how the court process can find out the truth and validity of legally valid land certificates.

The emergence of various cases of land disputes in Indonesia is one of its polemics in applying State Administrative Law in Indonesia. HAN wants and regulates how a country and its organs carry out their duties, namely serving the community fairly. There should be interpreted by all legal policies that are populist and do not harm the community.

Individuals ought to be cautious and cautious when purchasing area to keep away from debates later on. After the deal and acquisition of land, it is prudent to put forth an attempt to move land privileges by enrolling the land to the neighborhood Land Office. Carelessness in dealing with the exchange of land freedoms will expand the odds of acquiring a land endorsement in the future by different gatherings. It may be the case that the right holder whose name is as yet recorded in the land book of the Land Office deals with re-giving the authentication of the land that was sold. With the reason of being lost, the holder of the old land freedoms might get the testament he needs, then, at that point, sell the ground again to another person. The ramifications is that a legitimate question emerges because of the responsibility for land authentications against a similar item.

Before someone buys land, one should ask the seller and first, check the status of the land to find out if the land is girik or not. Residents who own land but only have tax documents on their land must immediately register the ground to not cause legal problems in the future. In its implementation, although land registration has been carried out, there are still frequent disputes over land rights during the community, which often even lead to lawsuits to the court, which results in blocking or even abrogation of the testament of land freedoms by the Office of the Republic of Indonesia. Land. There can bring about the gatherings getting the land, who will be fundamentally distraught despite the fact that they have followed the fitting techniques.

Article 32 section (1) of Government Regulation Number 24 of 1997 states that an endorsement is a proof of freedoms that applies as a piece of strong proof, however in passage 
(2) of the article, it expresses that if on a plot of land a testament has been given legitimately for the sake of an individual. Or then again a lawful element that gains the land in sincerely and controls it, the other party who feels he has freedoms to the land can at this point don't guarantee the execution of the right if inside a long time from the issuance of the authentication doesn't present a composed issue with the declaration holder and the Head of the Land Office concerned or don't document a claim to the court in regards to land residency or testament issuance.

\section{Methods}

This kind of examination is library research, specifically research that utilizes auxiliary information.[7] The source of the data is obtained through document search.[8] This kind of exploration is unmistakable. Unmistakable exploration, specifically lawful examination that is interpretive and expects to bring a total depiction (portrayal) of the predominant lawful conditions. This review plans to depict in a top to bottom with regards to the article under study.

Techniques The methodology in this review utilizing a regulating juridical framework is characterized as a strategy for acquiring information dependent on an evaluation of essential law, composed law, and optional lawful materials identified with research issues. One more name for standardizing legitimate examination is doctrinal lawful exploration, additionally alluded to as library examination or record study, called doctrinal lawful examination. Since this exploration is done or submitted distinctly on composed guidelines or other legitimate materials, it is supposed to be library examination or report study since this exploration is done primarily on optional information in the library.[9]

The wellspring of examination information utilizes optional information acquired by implication from the item, yet through different sources, both oral and composed, sourced from writing books, reports, laws and guidelines, and documents of past research identified with research. Auxiliary information is information acquired from essential lawful materials, optional lawful materials, and tertiary lawful materials. The information assortment procedure utilized in the exploration is library examination and report study, an information assortment apparatus that is helped out through composed information utilizing content investigation.

\section{Discussion}

\subsection{Factors Causing the Emergence of Dual Certificates of Land Rights}

Article 19 passage (2) letter c of the Basic Agrarian Law and Government Regulation Number 24 of 1997 Article 32 section (1) concerning Land Registration, affirms that: the juridical information contained in that, as long as the actual information and juridical information are following the information gathered in the letter of estimation and the book of land freedoms being referred to."

However long there could be no other proof that demonstrates falsehood, then, at that point, the data contained in the declaration should be thought of as right with no requirement for extra proof. Simultaneously, the other proof is just viewed as fundamental proof and should be upheld by other proof. Along these lines, a land authentication demonstrates that the right holder has an option to a specific plot of land. Where actual information incorporates 
data about the area, limits, and land region. Juridical information gives data with respect to the legitimate status of the land package, its privileges holders, the freedoms of different gatherings, and extra weights that trouble it.

In any case, alongside the high worth and advantages of land, many individuals are attempting to get evidence of land possession by having counterfeit declarations, veritable yet phony, or different authentications where the information on the endorsement doesn't coordinate with what is in the land book. The quantity of such certificates is very enormous, which makes a weakness. Phony of testaments happens in light of the fact that they are not founded on the right privileges, for example, the issuance of declarations dependent on a distorted endorsement of proprietorship, different structures as a National Land Agency (BPN) stamp, and misrepresentation of land information. Practically speaking, the endorsement holder without a particular period might lose his freedoms because of a claim from another party, bringing about the wiping out of the declaration because of regulatory, legitimate deformities. The presence of hierarchical law abandons causes twofold authentications in light of the fact that the accreditations are not planned in the land enrollment map or the circumstance guide of the space.

The lack of transparency regarding land tenure and ownership is caused by the limited data and information on land tenure and rights. The lack of transparency of data available in the community is one of the causes of land disputes. This causes the concentration of control and ownership of land in rural areas and several plots of land in urban areas, only in a small part of the community. On the other hand, land certificates still demand access, which far exceeds the supply side. However, land administration projects such as prone and adjudication projects have relatively succeeded in achieving their goals.

If we look closely, the land conflicts that have occurred so far have broad dimensions, horizontal and vertical rows. The most dominant standing competition is between the community and the government or state-owned companies and private companies. For example, one of the most prominent cases is the case of acknowledging a parcel of land or reclaiming it. Meanwhile, the most common horizontal conflict is the issue of multiple certificates or ownership of several certificates on a plot of land.

Another cause of land disputes is the high economic value of land, and land is a symbol of existence and social status in the community, resulting in vertical and horizontal land conflicts. The strategic and special meaning and value of land encourage everyone to own, maintain and care for their land correctly, if necessary, defend it with all their might until the last drop of blood.

The roots of conflicts and land disputes that are multidimensional cannot be seen as mere legal issues but are also related to other non-legal variables, including the weakness of land certification regulations that have not been maximized. The overlapping issuance of a decision from agencies directly related to land is also a factor in the emergence of land disputes.

Law Number 5 of 1960 concerning Basic Agrarian Basic Regulations proclaimed on September 24, 1960, known as the LoGA, carries out Article 33 passage (3) of the 1945 Constitution of the Republic of Indonesia. Prior to the sanctioning of the UUPA, just for lands that are dependent upon Western law, for instance, Eigendom privileges, Erpacht freedoms, Opstal privileges, land enlistment is completed to give legitimate assurance ensures, and the holder is given evidence with a deed made by the Transfer of Name Officials.

As per Government Regulation No. 24 of 1997, lawful assurance viewing land privileges as commanded by the BAL contains two aspects: conviction of objects of land freedoms and certainty of subjects of land freedoms. One sign of the conviction of the thing of land freedoms is shown by the lock of the area of the land bundle with geo-reference facilitates in a 
land enlistment map. Conversely, the assurance of the subject is demonstrated by the name of the holder of land privileges recorded in the land enlistment book at the land office. In synopsis, duplicates of the guides and land enlistment books are known as Land Certificates.

Testaments of land freedoms as the eventual outcome of the method involved with enlisting land privileges, including changes in regards to the topic, status of levy, and lawful activities completed on the land, are solid proof as expressed in the arrangements of Article 19 passage (1) letter c, Article 23 segment (2), Article 32 section (2) and Article 38 section (2) BAL. The endorsement is solid proof and isn't outright/ideal confirmation as indicated by the arrangements of the UUPA and the Government Regulation that carries out it (Government Regulation Number 10 of 1961 and Government Regulation Number 24 of 1997).

This implies that the data contained in it has legitimate power and should be acknowledged (by the appointed authority) as precise data as long as and as long as there is no proof to demonstrate in any case. In Article 32 passage (1) of Government Regulation Number 24 of 1997 , it is expressed that a testament is confirmation of right that applies as the slightest bit of strong proof, yet in section (2) of the article, it expresses that if on a plot of land a legitimate authentication has been given for the name of the individual or lawful substance that acquired the land in sincerely and controls it, then, at that point, the other party who feels he has freedoms to the land can presently don't request the execution of the right if inside 5 (five) a long time from the issuance of the endorsement doesn't document a proper complaint. Recorded as a hard copy to the declaration holder and the Head of the Land Office concerned or not to document a claim to the court with respect to land residency or endorsement issuance.

Noticing the above arrangements, it is still exceptionally open to the chance of impedance from parties who feel they have freedoms to the land or feel distraught by presenting an issue with the neighborhood Land Office and the holder of the testament of land privileges if the issuance of the endorsement of land freedoms has not been 5 (five) a long time. One of the issue peculiarities with regards to public land law is the regular appearance of different authentications (some are much more than two) in light of the detailing of Article 32 passage (2) of Government Regulation Number 24 of 1997 concerning Land Procurement which can bring about misfortunes to land purchasers with honest goals.

Issuance of authentications is likewise unmistakably directed in Government Regulation Number 24 of 1997 concerning Land Procurement; in Article 31, it is expressed that endorsements are given to assist the right holder worried about natural information, and juridical information have been enlisted in the land book. In case there are records concerning juridical information in the land book or depictions of physical or juridical information, the issuance of the endorsement is suspended until the significant reports are erased. The declaration may just be submitted to the party whose name is recorded in the land book worried as the right holder or to one more party approved by him. As to privileges or proprietorship freedoms to pads mutually possessed by a few group or legitimate substances, an authentication is given, which is gotten to one of the joint freedoms holders upon the other shared privileges holders' composed arrangement. In the mean time, in regards to one side to land or possession privileges to the loft unit which is mutually claimed, an authentication can be given as numerous as the quantity of joint freedoms holders to be given to each joint right holder concerned, which contains the name and the measure of each portion of the proportional right. Furthermore, the structure, content, technique for finishing up and marking the testament will be dictated by the Minister. 
Dual certificates are still a problem and have not been resolved due to several legal and non-legal factors. In terms of theory and opinions of experts, the factors causing the occurrence of double certificates are as follows:

1. Multiple certificates can occur due to several technical errors, namely:

a. When estimating or directing field research, the candidate deliberately or inadvertently shows some unacceptable area of the land and the limits of the land.

b. The presence of a letter of proof or affirmation of freedoms has been demonstrated to contain misrepresentation, lie, or is at this point not substantial.

c. There is no land registration map for the area concerned.

d. Cases of issuing more than one certificate on a plot of land can also occur on inherited land. The background of the matter is a dispute over inheritance, namely by the owner before his death. It has been sold to another party without being noticed by his children, and a certificate has been issued on behalf of the buyer. Then the heirs have certified the same land, resulting in a double certificate because the certificate previously had not been mapped.

2. The occurrence of multiple certificates is one of the consequences of overlapping in issuing land rights certificates which is called administrative law defects. As contained in Article 107 of the Regulation of the Minister of Agrarian Affairs/Head of the National Land Agency Number 9 of 1999 concerning Procedures for Granting and Cancellation of Land Rights and Management Rights, land privileges testaments that are officially imperfect are land freedoms endorsements that contain mistakes, among others as follows:

a. procedural error

b. misapplication of laws and guidelines

c. right subject error

d. rights object error

e. right type blunder

f. area computation blunder

g. there are covering land privileges

h. juridical information and actual information are not right;

i. other managerial mistakes

3. Internal and external factors influence the occurrence of double certificates. These factors are seen from within the Land Office agency. The internal factors in question are:

a. The non-implementation of the LoGA and its implementing regulations consistently and responsibly, besides that there are still people who act for personal gain. These factors are seen from within the Land Office agency.

b. Lack of functioning of the supervisory apparatus provides opportunities for subordinate officers to act defiantly in the sense of not carrying out their duties and responsibilities according to their oath of office.

c. The inaccuracy of Land Office officials in issuing land certificates, namely the documents that are the basis for the issuance of certificates, are not sifted through, which may not meet the prerequisites as dictated by the arrangements of the appropriate enactment.

d. The Land Office as a Government Agency in making and issuing land certificates is very dependent on data published by other government agencies such as regional/village governments and tax service offices.

Based on the factors of the emergence of the dual certificate, it is possible to have the form of a double certificate, namely: First, two or more certificates are genuine, but one of them is real but fake. This means that both have a copy/archive at the Regency/City Land Office. This 
can happen because a parcel of land that has been certified is re-registered at the Land Office, so both are original BPN products, but the object/plot of land is the same in terms of location, position, and area; Second, the two certificates are fake, meaning that the two certificates do not have a copy at the Land Office/BPN or there is no archive; Third, one or more certificates are part of another certificate. This happens because the registered land parcels should be registered through the process of splitting the parent certificate, or conversely, the issuance of one certificate should be a combination of several other certificates; Fourth, overlapping, i.e., there are two or more certificates that overlap with each other so that the overlapping part is a double certificate because some of the lands are included in another certificate.

Not a few certificates that are legally flawed in the form of falsification of certificates and double certificates, which are caused, among other things, by the non-implementation of the LoGA and its implementing regulations consistently and responsibly, in addition to the presence of people who are trying to obtain personal benefits. The carelessness factor of the land registration officer also accompanies the birth of a legal defect certificate caused by carelessness/inaccuracy in issuing the land certificate, meaning that the officer does not examine carefully even though the document does not meet the prerequisites as dictated by the appropriate laws and guidelines.

\subsection{Legal Protection for Land Rights Owners in the Case of Multiple Certificates}

The job of land for different purposes will increment in the current period of globalization and financial progression, both as a spot to live and business exercises. This will likewise build the requirement for help as lawful conviction in the land area. The arrangement of lawful assurance in the land area requires the accessibility of composed, complete, and exact legitimate instruments that are done reliably following the soul and content of the arrangements.

The execution of land enlistment exercises makes it feasible for holders of land freedoms to demonstrate their privileges to the land they control effectively and for invested individuals, like forthcoming purchasers and planned lenders, to get the vital data in regards to the land that is the object of the lawful activity to be done. Just as for the public authority to execute land arrangements. In such manner, Law Number 5 of 1960 concerning Basic Regulations on Agrarian Principles, Article 19 orders the holding of land enrollment to ensure the said legitimate conviction.

The execution of land enlistment is then directed in Government Regulation Number 10 of 1961 concerning Land Registration. In the interim, the lawful arrangements contained in Government Regulation Number 10 of 1961 for the premise of its execution are felt to be deficient to give the likelihood to the presentation of land enlistment in a quick time with more acceptable outcomes. Unofficial law Number 10 of 1961 has been refined into Government Regulation Number 24 of 1997 concerning Land Registration.

The Government Regulation Number 24 of 1997 still keeps up with the goals and the framework utilized, which fundamentally has been specified in the Basic Agrarian Law, in particular that land enrollment is completed to ensure lawful conviction in the land area and that the distribution framework is negative, yet contains the ideal component since it will create letters of confirmation of privileges that apply as solid proof, as expressed in Article 19 passage (2) letter c, Article 23 segment (2), Article 32 section (2) and Article 38 section (2) UUPA. The sound of every one of the Articles of the LoGA can be portrayed as follows:

Article 19 UUPA: 
1. To ensure legitimate sureness by the public authority, land enlistment is completed all through the region of the Republic of Indonesia as per the arrangements specified in a Government Regulation.

2. The enlistment in passage (1) of this article incorporates a) planning and land accounting estimations; b) enrollment of land privileges and the exchange of such freedoms; c. the arrangement of letters of verification of exemplary nature, which fills in as an amazing method for proof.

3. Land enlistment is done considering the state of the State and society, the requirement for financial traffic, and the chance of its execution, as per the thought of the Minister of Agrarian Affairs.

4. The Government Regulation manages the expenses related with the enlistment as alluded to in passage (1) above, gave that individuals who can't bear the cost of it are excluded from paying these charges.

Article 19 section (2) letter c, the planned legitimate insurance is parties who have enlisted land as indicated by the arrangements specified by unofficial laws. The public authority ensures lawful conviction by getting confirmation of privileges archives, which fill in as strong proof. As an indication of land possession. Article 23 UUPA:

1. Property rights and any transfers, cancellations, and encumbrances with other requests must be registered according to the provisions referred to in Article 19.

2. The enlistment in section (1) is an amazing method for verification in regards to the invalidation of property privileges and the legitimacy of the exchange and task of such freedoms.

Each move of possession freedoms to land, its annulment, and encumbrance with different solicitations should be enlisted following the arrangements specified by a Government Regulation. As legitimate assurance as alluded to in Article 23 section (2), to be specific the enrollment that has been done for the exchange and cancelation and encumbrance of different gatherings, is an incredible method for verification in regards to the annulment of property freedoms and the legitimacy of the exchange and task of such privileges. Article 32 UUPA:

1. Development freedoms, including the conditions for allowing them, just as any exchange and disposal of such privileges, should be enrolled by the arrangements alluded to in Article 19.

2. As referenced in passage (1), the enlistment is an incredible method for confirmation with respect to the exchange and the revocation of the option to develop, aside from if the solicitation is invalidated in light of the fact that the term has lapsed.

Each move and cancelation of land use freedoms, including the conditions for giving them, should be enrolled by the arrangements specified by unofficial laws. The legitimate insurance alluded to in Article 32 section (2), to be specific the enrollment of the exchange and the cancelation of the option to develop the land, including the conditions for giving it, is an incredible method for confirmation with respect to the exchange and the disintegration of the option to create, besides for the situation that the solicitation is repealed because of a period. The time is finished. Article 38 of the LoGA:

1. The option to construct, including the conditions for allowing it, and any exchange and revocation of the solicitation should be enlisted by the arrangements alluded to in Article 19 .

2. The enrollment as alluded to in passage (1) is an amazing method for evidence with respect to the invalidation of the option to fabricate and the legitimateness of the exchange of the possession, besides for the situation that the solicitation is dissolved on the grounds that its term has lapsed. 
Each move and abrogation of building use freedoms ashore, including the conditions for giving it, should be enrolled by the arrangements specified by unofficial laws. The lawful security as alluded to in Article 38 section (2), in particular the enlistment of the exchange and the invalidation of the option to utilize a structure on the land, including the conditions for its award, is an incredible method for evidence in regards to the revocation of the option to utilize the office and the legitimateness of the exchange of the solicitation, with the exception of that right. Erase this is on the grounds that the period is finished.

Legitimate security for the proprietor of land freedoms in case there are various authentications other than those referenced in the articles referenced above, Article 32 passage (1) of Government Regulation Number 24 of 1997 additionally gives lawful assurance which expresses that "Endorsements are confirmation of privileges that apply as a solid method for evidence with respect to the actual information and juridical information contained in that, as long as the actual information and juridical information are under those contained in the letter of estimation and the applicable land book."

This arrangement infers that as long as the opposite has not been demonstrated, natural information and juridical information remembered for the endorsement should be acknowledged as right information, both in every day legitimate activities and in questions in court, as long as the information is following what is expressed in the letter: estimating and the pertinent land book. The association with the common legal dispute analyzed and attempted at the Tangerang District Court in regards to land debates emerging from double authentications brings up the issue of the degree to which the State can give legitimate security to land freedoms holders as it is perceived that the right to lawful insurance concerns the obligations, jobs, and obligations that the force of state character should complete. As residents who accumulate in a state personality, they have essential privileges, specifically the right to wellbeing, security, and lawful insurance. As a result of the acknowledgment of these freedoms, it isn't took into consideration any citizen as a resident to get uncalled for administrations from the force of the State.

Then, at that point, considering the arrangements in Article 32 passage (2) of Government Regulation Number 24 of 1997, that "if a land package has been lawfully given for the sake of the individual or lawful substance that procured the land in sincerely and controlled it, then, at that point, the other people who feel they have freedoms to the land will presently don't request the activity of that right if inside 5 (five) a long time since the issuance of the declaration they have not presented a composed issue with the endorsement holder and the Head of the Land Office concerned or have not recorded a claim with the court in regards to land residency. Or then again issuance of the authentication".

The National Land Agency (BPN) was framed dependent on the Decree of the President of the Republic of Indonesia Number 25 of 1988 as an improvement from the Directorate General of Agrarian Affairs at the Ministry of Home Affairs and is a Non-Departmental Government Institution (LPND) situated under and capable to the President. The primary errand of the National Land Agency (BPN) is to help the President in overseeing and fostering the Land Administration both dependent on the LoGA and different laws and guidelines which incorporate Regulation, Use, Control and Ownership of land, Measurement of Land Rights, Measurement and Registration of Land, and others. - Others identified with land issues dependent on approaches controlled by the President.

So the functions and duties of the role of BPN to prevent the occurrence of double certificates there is no other way to optimize land administration and make land registration maps. This must be done to avoid duplicate certificates from occurring. With a map of land registration and good land administration, misplacement of locations and boundaries can be 
identified as early as possible. The certificate of the legal defect must be blocked (noted in the land book), stopped (the process is withheld), turned off (the correct number is crossed out from the land book), canceled when the case is finished.

Based on the Presidential Regulation of the Republic of Indonesia Number 10 of 2006 concerning the National Land Agency, the functions and duties of the BPN for mapping efforts have been stated in Article 3 letter e, Article 9 paragraph (1) and (2) that Article 3 letter words that: "Organization and implementation of surveys, measurements, and mapping in the land sector." Article 9 paragraph (1) states that: "Deputies for a survey, measurement, and mapping are elements implementing some of the duties and functions of the National Land Agency in the field of surveys, measurements, and mapping which are under and responsible to the Head." Article 9 paragraph (2) states that: "Deputies for the survey, measurement, and mapping have the task of formulating and implementing policies in the field of surveys, measurements, and mapping."

According to Eddy Ruchiyat[10], in his book "National Land Politics Until the Reformation Order," the effort to prevent double certificates is to be continuously carried out by completing maps of land registration in areas where such maps are not yet available. With the availability of a complete Land Registration map, it is hoped that double certificates can be prevented from being issued.

Legitimate conviction in land enrollment intends to accomplish lawful insurance for holders of land privileges. Along these lines any issues that emerge when a debate is moving in court should go through a proof interaction. As far as legitimate conviction, Government Regulation Number 24 of 1997 gives a sensibly solid assurance contrasted with Government Regulation Number 10 of 1961. Unofficial law Number 10 of 1961 doesn't indicate a specific opportunity to give conviction. The declaration as confirmation of land possession can in any case be dropped in case there is proof of information utilized as the reason for the issuance of deformities. In the interim, Government Regulation No. 24/1997 states that following five years have passed in the wake of being given, the land authentication can at this point don't be challenged so it will give generally more lawful conviction and lawful assurance.

Issuance of testaments of land freedoms by the Land Office is a lawful activity in state organization. For this situation, as a state regulatory organization, the National Land Agency completes its obligations directed by the material laws and guidelines and improved by Government Regulation Number 24 of 1997. Consequently, the issuance of endorsements of land privileges by the National Land Agency is constitutive, specifically government managerial choices that have legitimate results. The lawful outcome is that the state ensures and secures the proprietor of the endorsement of land privileges.

The connection between the issuance of authentications of land freedoms and legitimate sureness is causal. Unofficial law Number 24 of 1997 has set up legitimate conviction better than Government Regulation Number 10 of 1961. In the event that the Government Regulation Number 10 of 1961 has not indicated a period limit for outsiders to sue the proprietor of the declaration of land freedoms, despite what is generally expected, Government Regulation Number 24 In 1997, Article 32 section (2) specifies as far as possible for an outsider to record a claim, which is a long time from the issuance of the endorsement of land privileges.

Albeit the rule of rechtsverwerking is applied to give lawful conviction to parties who in sincerely control the land and are enrolled as privileges holders in the land book with a testament of land freedoms as confirmation of proprietorship, the rule of rechtsverwerking will be inadequate or unfit to give lawful security and can unfavorable to the party who possesses the land yet can't demonstrate it was using an authentication of land freedoms. Legitimate 
safeguard is likewise difficult to provide for land freedoms holders who acquire land privileges just dependent on great confidence.

Article 1320 to Article 1337 of the Civil Code contains an insistence that an understanding will void if it incorporates compulsion, extortion, oversight, ineptitude of the producer, and without cause (causa not halal). Accordingly, if during the time spent moving or acquiring a declaration of land freedoms there are components alluded to in Article 1320 to Article 1337 of the Civil Code, then, at that point, the land authentication claimed by an individual has not shown that individual as the genuine right holder. In such conditions, the testament of land privileges can be dropped whenever if it would seem there is another party who can legitimately demonstrate that he is the real proprietor.

As opposed to the lively land enlistment framework, the evidence of an individual's on the whole correct to land is outright and can't be challenged. On the off chance that it would appear there is lacking proof appearance a legitimate imperfection from the obtaining of the solicitation. He can't request dropping, aside from requests for installment of pay. On the off chance that it would seem there is a blunder or error in the issuance of a declaration of land freedoms, it should go through a legitimate component to address the lawful outcomes. In this episode, obviously, a few gatherings are hurt. The wronged party is qualified for and should be made up for the misfortune. The reason for applying for remuneration depends on Article 1365 of the Civil Code.

Double endorsements bring about legitimate vulnerability for land privileges holders, which is exceptionally bothersome in the execution of land enrollment in Indonesia. One of the issues emerging from double endorsements is who can drop one of the two declarations. Along these lines, the court should decide, survey, and conclude who has the option to claim the land for the situation dependent on the proof and declarations of witnesses. Assume the court has settled on a land proprietorship case that has long-lasting lawful power (in kracht van gewijsde). All things considered, the triumphant party should apply for the Head of the BPN/Land Office, which drops the declaration of the crushed party.

\section{Conclusion}

Factors causing the occurrence of dual certificates of land rights, among others due to technical errors during the measurement, the existence of a letter of evidence or acknowledgment of rights (untruth, false, or no longer valid), land inheritance disputes; due to overlapping in the issuance of land rights certificates, which are called administrative-legal defects; and the existence of internal and external factors of the Land Office agency.

Lawful insurance for the proprietor of land privileges in case of a twofold testament, specifically acquiring legitimate security as specified in the Law of the Republic of Indonesia Number 5 of 1960 concerning Basic Agrarian Regulations (UUPA) Article 19 passage (2) letter c, Article 23 segment (2), Article 32 section (2) and Article 38 passage (2), and Government Regulation No. 24 of 1997 Article 32 section (1), that the letters of verification of privileges apply as a piece of strong proof. If it would appear there is a blunder or error in the issuance of a testament of land freedoms, it should go through a legitimate system to address the lawful results. Obviously, a few gatherings were hurt in this episode. The distressed party is qualified for and should be made up for the misfortune. The reason for applying for remuneration depends on Article 1365 of the Civil Code.

The government must decide that the only institution that manages land administration is the National Land Agency and other institutions only follow the instructions or rules issued by 
the BPN. The land registration map, the land registration database owned by BPN should be used properly so that there will be no more plots of land with multiple certificates. If this happens, it will be known from the land registration map owned by BPN.

\section{References}

[1] B. Biswas, International political economy: Perspectives on global power and wealth, vol. 3, no. 3. 1994.

[2] A. Darmawan, "Politik Hukum Omnibus Law Dalam Konteks," Indones. J. Law Policy Stud., vol. 1, no. 1, pp. 14-25, 2020.

[3] E. E. Supriyanto, "Politik Kebijakan Ketahanan Pangan Indonesia Pasca Pandemi Covid-19," in Pertanian Dalam Ketahanan Pangan Selama dan Sesudah Covid-19, vol. 1, no. 1, Denpasar: Penerbit Yayasan Guna Widya Paramesthi, 2021, pp. 33-43.

[4] M. S. W. Sumardjono, "Kebijakan Pertanahan: antara Regulasi dan Implementasi Kompas," Jakarta Juni, 2001.

[5] L. Benhard, "Politik Pertanahan," Pustaka Margaretha, Jakarta, 2014.

[6] Undang-Undang No. 5 Tahun 1960 Tentang Peraturan Dasar Pokok-Pokok Agraria. .

[7] C. Maguire, "Library research: Luxury or necessity?," Aust. Libr. J., vol. 60, no. 4, pp. 298-303, 2011, doi: 10.1080/00049670.2011.10722646.

[8] S. Houghton-Jan, A. Etches-Johnson, and A. Schmidt, "The read/write web and the future of library research," J. Libr. Adm., vol. 49, no. 4, pp. 365-382, 2009, doi: 10.1080/01930820902832496.

[9] J. J. Little, "Cognitive load theory and library research guides," Internet Ref. Serv. Q., vol. 15, no. 1, pp. 53-63, 2010, doi: 10.1080/10875300903530199.

[10] E. Ruchiyat, "Politik Pertanahan Sampai Orde Reformasi," Bandung: Alumni, 2004. 